\title{
İHA Bataryasının Şarj Pedi ile Dengeli Şarj Edilmesi ve Gerçek Zamanlı İzleme Sistemi
}

\section{Balanced Charging of UAV Battery with Charging Pad and Real Time Monitoring System}

\author{
Hakan Üçgün ${ }^{1 *}$, Uğur Yüzgeç ${ }^{2}$, Cüneyt Bayılmış
}

Geliş / Received: 02/05/2021

Revize / Revised: 08/06/2021

Kabul / Accepted: 10/06/2021

ÖZ

Elektronik sistemlerin ayrılmaz bir parçası olan bataryalar, güç kaynağı olarak önemli roller oynamaktadırlar. Günümüzde mobil araçlar, elektronik cihazlar ve yedek güç gibi birçok alanda şarj edilebilir bataryalar kullanılmaktadır. Bataryaların şarj veya deşarj işlemi sırasında takip edilmesi, performans açısından bataryanın ömrünün korunmasını ve güvenliğini sağlamaktadır. Batarya Yönetim Sistemleri (BMS: Battery Management Systems), bataryanın sahip olduğu hücreleri, balanslı bir şekilde şarj veya deşarj ederek hücrelerdeki dengenin korunmasını sağlamaktadır. Bu sistemler, bataryaların ömrünü uzatabilme ve optimize edebilme imkânı sağlar. Bu çalı̧̧ma kapsamında, İnsansız Hava Araçlarında (İHA) kullanılan Lityum Polimer (LiPo) bataryalarının şarj işlemi sırasında takip edilmesine imkân sağlayacak bir sistem gerçekleştirilmiştir. Geliştirilen sistem ile LiPo bataryasının hücre gerilim değerleri, hazırlanan bir arayüz ile gerçek zamanlı olarak takip edilebilmektedir.

Anahtar Kelimeler- IHA, LiPo Batarya Şarj, Gerçek Zamanlı İzleme, Batarya Yönetim Sistemi

\begin{abstract}
Batteries, which are an essential part of electronic systems, play an important role as a power source. Today, rechargeable batteries are used in many areas, such as mobile vehicles, electronic devices, and backup power. Monitoring the batteries during the charging or discharging process ensures the protection and safety of the battery life in terms of performance. Battery Management Systems (BMS) ensure that the balance in the cells is maintained by charging or discharging the cells of the battery in a balanced way. These systems provide the ability to extend the life and optimize of the batteries. In this study, a system has been developed that will allow the monitoring of Lithium Polymer (LiPo) batteries used in Unmanned Aerial Vehicles (UAV) during the charging process. With the developed system, the voltage values of the LiPo battery cells are monitored in real time with an interface.
\end{abstract}

1*Sorumlu yazar iletişim: hakan.ucgun@bilecik.edu.tr (https://orcid.org/0000-0002-9448-0679)

Bilgi İșlem Daire Bașkanlı̆̆ı, Bilecik Seyh Edebali Üniversitesi, Bilecik, Türkiye

2illetişim: ugur.yuzgec@bilecik.edu.tr (https://orcid.org/0000-0002-5364-6265)

Bilgisayar Mühendisliği, Mühendislik Fakültesi, Bilecik Şeyh Edebali Üniversitesi, Bilecik, Türkiye

3iletişim: cbayilmis@sakarya.edu.tr (https://orcid.org/0000-0003-1058-7100)

Bilgisayar Mühendisliği, Bilgisayar ve Bilişim Bilimleri Fakültesi, Sakarya Üniversitesi, Sakarya, Türkiye 


\section{GİRIŞ}

Günümüz teknolojisinin ilerlemesiyle birlikte pek çok uygulama son kullanıcıya sunulmuştur. İlk zamanlarda askeri amaçlarla görev yapan İnsansız Hava Araçları (IHA), günümüzde pek çok farklı alanda kullanılmakta ve gördüğü ilgi gün geçtikçe artmaktadır [1]. Farklı yapılara ve şekillere sahip olan İHA'lar, uzun süreli ve dayanıklılık gerektiren görevlerde kullanılabilirler ve genel olarak yüksek manevra kabiliyeti, otonom uçuş, konum takibi, esnek uçuş gibi kabiliyetlere sahiptirler [2, 3]. Pek çok avantajının olmasının yanı sıra düşük uçuş süresi, sınırlı yük miktarı gibi dezavantajları da bulunmaktadır.

İHA'larda enerji kaynağı olarak çoğunlukla yüksek yoğunluklu Lityum Polimer (LiPo) bataryalar kullanılmaktadır $[4,5]$. NiMh ve NiCd gibi bataryalarla karşılaştırıldığında, LiPo bataryasının yüksek enerji yoğunluğu, düşük deşarj oranı, yüksek hücre voltajı, esnek form faktörü, bellek etkisi eksikliği ve benzeri gibi birçok avantajı bulunmaktadır [6,7]. LiPo bataryaları, sıcaklık etkisi, elektrik yükü ve kullanım ömrü gibi parametreler yüzünden bazı sorunlar yaşamakta ve buna bağlı olarak düşük sürelerde deşarj olmaktadırlar. $\mathrm{Bu}$ durumun sonucunda İHA'ların uçuş süresini azalmaktadır [8].

LiPo bataryalarda depolanan enerjinin daha verimli kullanılması ve bataryanın dengeli şarj/deşarj işleminin gerçekleştirilmesi için Batarya Yönetim Sistemleri (BMS: Battery Management Systems) kullanılmaktadır [1]. BMS'ler, LiPo bataryalar için anahtar modülü görevi görürler. Şarj/deşarj parametrelerinin kontrolü, batarya hücrelerinin voltajlarının ve şarj durumunun ölçümü, batarya hücrelerinin şarj/deşarj özelliklerinin eşitlenmesi, ana denetleyiciye batarya paketinin durumu hakkında bilgi verilmesi gibi işlemleri yapmaktadırlar. Bataryalara gelebilecek olası hasarlara karşı da kritik önlemler alabilmektedirler [6]. Bu görevleri gerçekleştirmek için BMS'ler, bataryanın şarj durumunu (SoC: State of Charge) ve Kalan Kullanım Ömrü (RUL: Remaining Useful Life) [9] hakkındaki bilgileri kullanmaktadır.

Şarj işlemi esnasında balanslı veya balanssız olarak şarj edilen bataryaların hücrelerinde isınma, şişme ve yapısal olarak bozulmalar meydana gelebilmektedir. Bu gibi problemlerin meydana gelmesi bataryaların kullanım ömrünün kısalmasına veya tamamen bozulmasına neden olabilmektedir. Bataryaların şarj işlemi sırasında takip edilmesi ile meydana gelebilecek hücresel ısınma, şişkinlik ve yapısal bozulmalara karşı müdahaleler yapılarak ortaya çıkabilecek problemler engellenebilmektedir.

Bu çalışma kapsamında, İHA'larda kullanılan LiPo bataryasının BMS modülü aracilığıyla şarj edilmesi ve şarj işlemi sırasında bataryanın hücre gerilim değerlerinin gerçek zamanlı olarak takip edilebilmesine imkân sağlayacak bir sistem gerçekleş̧irilmiştir. Sistemde denetleyici olarak Arduino Uno mikrodenetleyici kartı kullanılmıştır. Sistemde bataryanın hücrelerinden gelen gerilim değerlerini almak için gerilim bölücü devre kullanılmıştır. LiPo bataryasının şarjı esnasındaki hücre gerilim değerlerini izlemek için bir arayüz tasarlanmıştır. Arduino ile arayüz arasında kablolu veri aktarım işlemi yapılmıştır. Elde edilen veriler grafiksel olarak kullanıcıya aktarılmıştır. Gerçekleştirilen çalışma, düşük maliyetli bir izleme sistemi sunmasının yanı sıra LiPo bataryasının balanslı bir şekilde şarj edilmesi ile performansının artırılmasına imkân sağlamaktadır.

\section{BATARYA ŞARJ IZLLEME SISTEMI MATERYALLERI}

İHA bataryalarının şarj edilmesi esnasında takip edilmesine imkân vermek amacıyla gerçekleştirilen sistemin çalışma prensibi Şekil 1'de verilmiştir. Gerçekleştirilen sistemde, İHA üzerinden bulunan bataryayı şarj etmek için bir şarj pedi kullanılmıştır. Şarj işlemi, İHA'nın bacaklarında bulunan konektörlerin şarj pedine temas etmesiyle başlamaktadır. Temas işleminden sonra BMS modülüne bağlı olan LiPo bataryasına enerji akışı başlatılmaktadır. LiPo bataryasındaki hücrelerin sahip oldukları gerilim değerleri BMS modülü aracıllğıyla alınmaktadır. Hücrelerden elde edilen gerilim değerleri, gerilim bölücü devreler aracıllğıyla Arduino Uno kontrolcü kartına analog olarak gönderilmektedir. Arduino kartı içerisinde işlenen veriler seri haberleşme yöntemi ile uygulama arayüzüne gönderilir. Uygulama arayüzü ile anlık LiPo bataryasının hücre bilgileri kullanıcıya aktarılmaktadır.

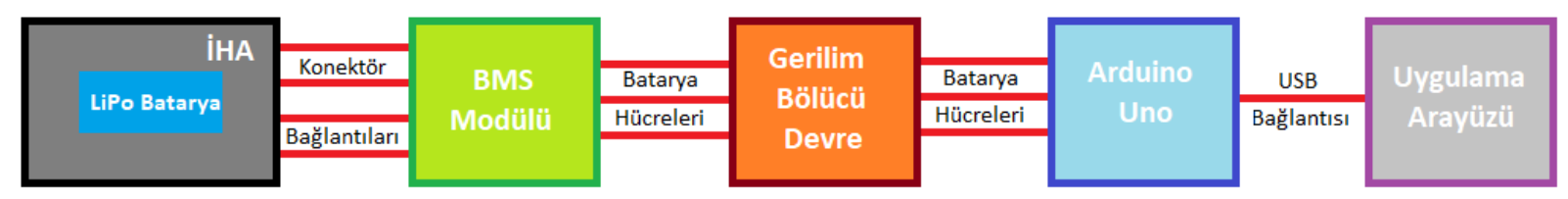

Şekil 1. Batarya Şarj İzleme Sisteminin Çalışma Prensibi 


\begin{tabular}{|c|c|c|}
\hline & $\begin{array}{l}\text { BŞEÜ Fen Bilimleri Dergisi } \\
8(1), 398-407,2021\end{array}$ & $\begin{array}{r}\text { BSEU Journal of Science } \\
\text { https://doi.org/10.35193/bseufbd.931613 }\end{array}$ \\
\hline $\begin{array}{l}\text { KSEEY } \\
\text { VERS }\end{array}$ & & 2458-7575 (https://dergipark.org.tr/tr/pub/bseufbd) \\
\hline
\end{tabular}

\section{A. Batarya Yönetim Sistemi (BMS: Battery Management Systems)}

Elektronik cihazlarda kullanılan çok hücreli Lityum bataryaların performanslarını belirleyen en önemli hususlardan birisi, hücrelerdeki şarj dengesidir. Bu durum bataryaların kullanım ömrüne etki etmektedir. Batarya yönetim sistemlerinin, ana işlevi batarya şarj dengesinin korunmasıdır [10]. BMS, şarj edilebilir bir pil hücresini veya pil paketini yöneten elektronik bir sistemdir. Batarya sistemlerinde bir koruyucu gibi davranarak bataryaların o andaki çalışma durumlarını inceleyip optimum çalışma değer aralıklarında kalmalarını sağlar. Her bir hücredeki ortaya çıkan uyumsuzlukları, diğer elektriksel ve termal anormallikleri izleyerek bataryanın güvenliğini ve verimliliğini sağlar [11].

BMS kartları, batarya verimini en üst düzeyde tutmak ve şarj esnasında aşırı şarj durumunu ortadan kaldırmak amacıyla hücrelerdeki sıcaklık, akım, voltaj gibi parametrelerdeki değişiklikleri takip ederler. Yapılan ölçüm ve hesaplamaların ardından optimal değerlerin aşılması durumunda gerektiğinde şarj sistemine müdahalede bulunarak sistemin korunmasını sağlarlar. Gerekli durumlarda en yüksek gerilimli hücreden en düşük gerilimli hücreye enerji akışı sağlanmaktadır. Şekil 2'de BMS kartı ile LiPo bataryası arasındaki bağlantı diyagramı verilmiştir. Kart üzerindeki;

- B- girişi LiPo'nun hem “-” hattına hem de balans soketinin 4. soketine hattının girişine,

- B1 hatt1 balans soketinin 3. soketine,

- B2 hattı balans soketinin 2. soketine,

- B+ hattı ise Balans soketinin 1. soketine hem de LiPo'nun “+” hattına bağlanmaktadır.

- P+ ve P- hatlarına şebekeden verilen gücün “+” ve "-” hatları bağlanmıştır.

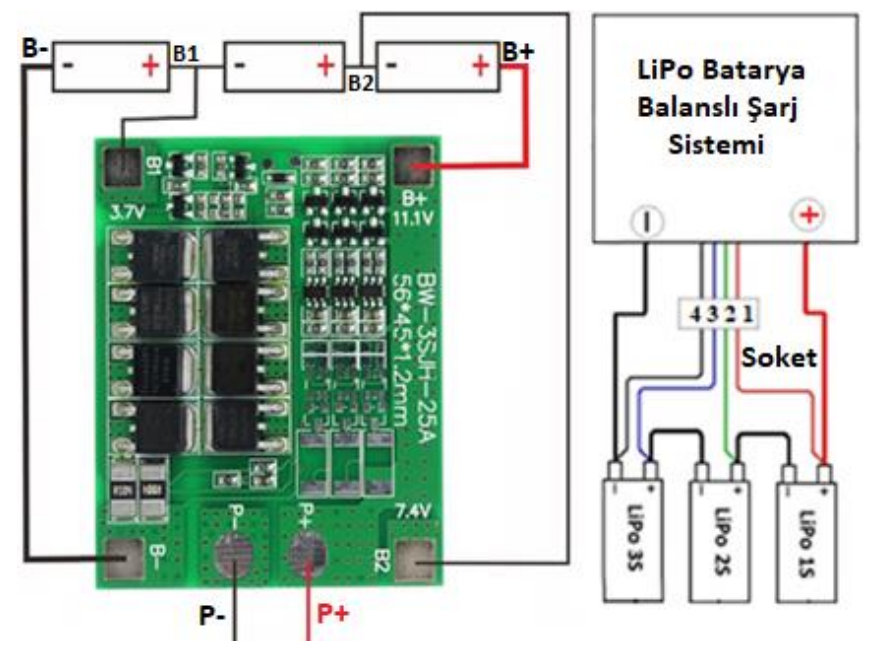

Şekil 2. BMS kartı ile LiPo Batarya Arasındaki Bağlantı Diyagramı

\section{B. Arduino Uno Mikrodenetleyicisi}

Açık kaynaklı bir elektronik platform olan Arduino, günümüzde donanımsal ve yazılımsal pek çok projede kullanılabilir hale gelmiştir. Üzerinde bulunan pinler aracıllğıyla çeşitli donanımların kullanılmasına imkân sağlayan kart, IDE ortamında geliştirilen yazılımlar ile kontrol edilebilmektedir. Arduino'nun basit, anlaşılması ve kullanımı kolay bir sözdizimi vardır [12]. Arduino Uno kartı, en sık kullanılan kartlardan bir tanesidir. Kart içerisinde, $16 \mathrm{MHz}$ Atmega328 işlemcisi, $32 \mathrm{~KB}$ program hafizası, 1 KB EEPROM, 2 KB RAM, 14 dijital, 6 analog G/Ç pini bulunmaktadır [13]. Kart sahip olduğu donanımsal birimler aracılığıyla IoT sistemleri, elektronik araçlar, gömülü uygulamalar gibi pek çok projelerde kullanılmaktadır.

\section{Gerilim Bölücü Devre}

Gerilim bölücü devreleri, girişe uygulanan yüksek seviyedeki voltajları, alçak seviyelere indirmek için kullanılan devrelerdir. Gerilim bölücü işlemi genel olarak iki adet direnç kullanılarak yapılmaktadır. Dirençlerin kullanıldığı bölücü devrelerinde yüksek seviyeli giriş gerilimleri farklı voltaj dilimlerine ayrılır ve ölçülebilir bir seviyede çıkış gerilimi elde edilir [14]. Çıkış gerilimi, Denklem (1) ile hesaplanmaktadır. 


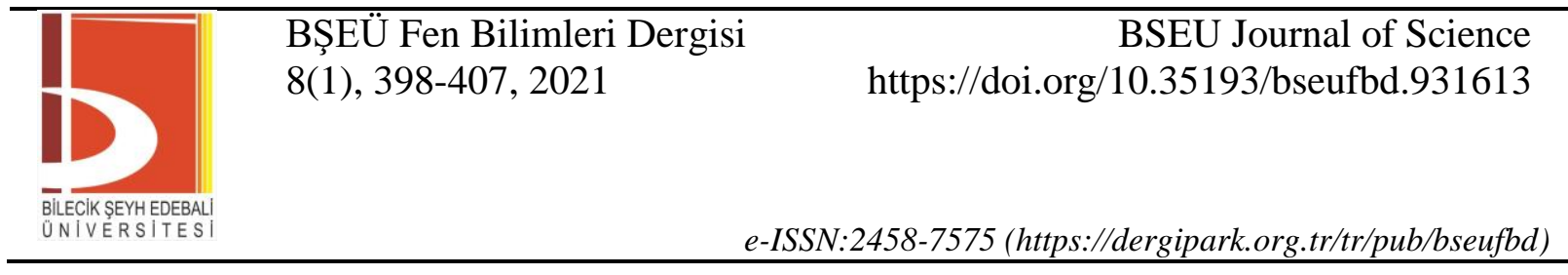

$$
\mathrm{V}_{\text {Out }}=\left(\mathrm{V}_{\text {In }} \times \mathrm{R}_{\text {Alt }}\right) /\left(\mathrm{R}_{\text {Ust }}+\mathrm{R}_{\text {Alt }}\right)
$$

Mikroişlemcilerde, sensör değerlerini ölçmek için gerilim bölücü devreleri kullanılmaktadır. Çalışma kapsamında kullanılan Arduino kartııın girişi seviyesinin maksimum 5 volt olması ve LiPo batarya hücrelerinden elde edilen voltaj değerlerinin (maksimum 4.2, 8.4 ve 12.6) olması sebebiyle herhangi bir problem yaşanmaması için gerilim bölücü devresi kullanılmıştır. Bu devre aracıllğıyla batarya hücrelerinin maksimum voltaj seviyesi 4.2 volt olacak şekilde ayarlanmıştır. Bu sayede, Arduino kartında meydana gelebilecek elektriksel problemlerin önüne geçilmiştir.

\section{Kullanıcı Arayüzü}

Çalışma kapsamında akım ve gerilim değerlerinin gerçek zamanlı ve anlık olarak izlenmesini sağlamak amacıyla bir kullanıcı arayüzü hazırlanmıştır. Masaüstü uygulaması olarak gerçekleştirilen arayüz, C\# programlama dili kullanılarak geliştirilmiştir. Arduino Uno kartı ile arayüz arasında seri haberleşme protokolü ile veri alışverişi yapılmaktadır. Arayüzde ilk olarak, Arduino Uno mikrodenetleyici kartı ile bilgisayarın seri haberleşmesini sağlayan port kontrolü ve bağlantısı yapılmaktadır. Seri port bağlantısının yapılmasından sonra, Arduino kartı aracılığıyla LiPo bataryasının voltaj değerleri 2 sn. aralıklarla arayüze gönderilmektedir. Seri port üzerinden gelen hücresel ve toplam voltaj değerlerine ek olarak anlık tarih ve saat bilgileri eklenerek arayüz üzerinden kullanıcılara aktarılmaktadır. Alınan veriler arayüz üzerinden takip edilmekte ve kullanıcı tarafindan kaydedilmektedir. Kaydedilen veriler daha sonra grafiksel olarak kullanıcılara aktarılmaktadır.

\section{BATARYA ŞARJ IZLEME SISTEMININ TASARIMI}

Batarya şarj izleme sistemi iki aşamalı olarak yapılmaktadır. İlk aşamada İHA, şarj pedine iniş yaptığında şarj işlemi başlayacak, ikinci aşamada ise şarj esnasında takip işlemini yapacak olan sistem devreye girecektir. Geliştirilen şarj sisteminde İHA'nın ayaklarına bağlı konektörler ile şarj ped'inin, İHA'nın iniş şekline bakılmaksızın ve kısa devre olma ihtimalini ortadan kaldırarak, temas etmesiyle şarj işleminin yapılabilmesi amaçlanmıştır. Bu sebeple İHA üzerindeki konektörlerin uçlarına köprü diyotları bağlanmıştır. Konektörlerin pozitif uçları bir diyottayken, negatif uçları ise diğer diyota bağlanmıştır. İniş sırasındaki kutup değişikliklerinden meydana gelebilecek kısa devre durumları bu şekilde aşılmaktadır.

LiPo bataryasının BMS kartı ve şarj ped'i aracıllğıyla şarj edilmesi işlemine ait blok diyagramı Şekil 3 'te verilmiştir. Geliştirilen sistemde, ilk olarak LiPo batarya ile BMS kartı, güç kabloları ve hücre bilgilerini veren balans kablosu aracılığıyla birbirlerine bağlanır. Bağlantı sonrası LiPo bataryasına ait hücrelerin gerilim değerleri ve toplam gerilim değeri BMS kartı aracılı̆̆ıyla okunabilmektedir. İkinci adımda, BMS kartı ile köprü diyot grubu arasında güç kabloları ile bağlantı yapılarak LiPo bataryaya şarj ped'i üzerinden güç verecek sistemin ilk aşaması gerçekleştirilmiş olur. Köprü diyot grubuna bağlanan ve İHA'nın bacaklarına yerleştirilen bakır konektörlerin, şarj ped'ine teması halinde güç aktarımı gerçekleştirilerek BMS kartı aracılığıyla LiPo bataryanın balanslı bir şekilde şarj edilmesi sağlanacaktır.

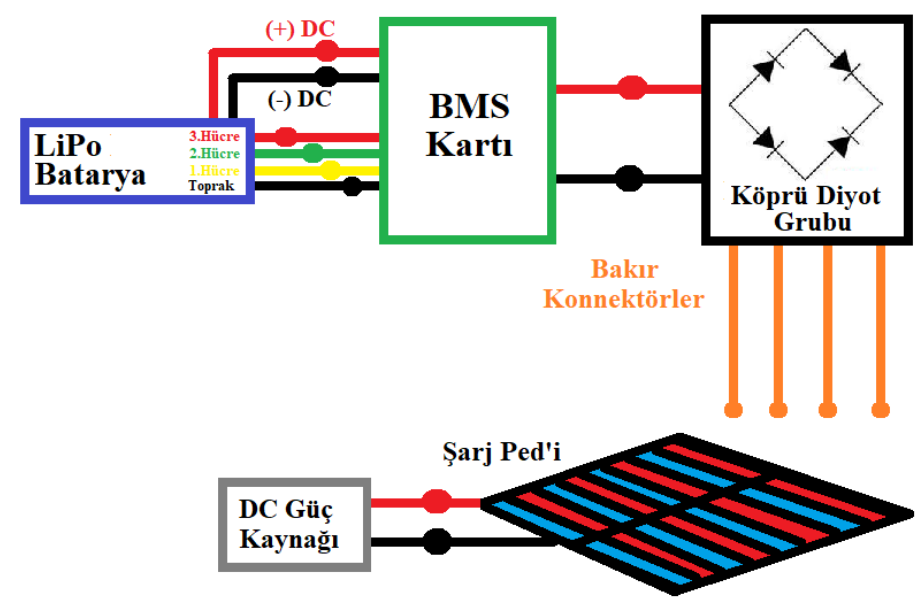

Şekil 3. Geliştirilen Şarj Sistemi Blok Diyagramı 
LiPo bataryasının hücre gerilim bilgilerinin, BMS ve Arduino kartları aracılığıyla transfer edilmesi işlemine ait blok diyagramı Şekil 4’te gösterilmiştir. BMS kartı üzerinden elde edilen hücre voltaj bilgileri gerilim bölücü devre aracılığıyla Arduino kartının analog girişlerine aktarılmaktadır. Kart içerisinde yapılan işlemler ile hücre bilgileri elde edilmekte ve seri iletişim protokolü aracılığıyla kullanıcı arayüzüne aktarılmaktadır.

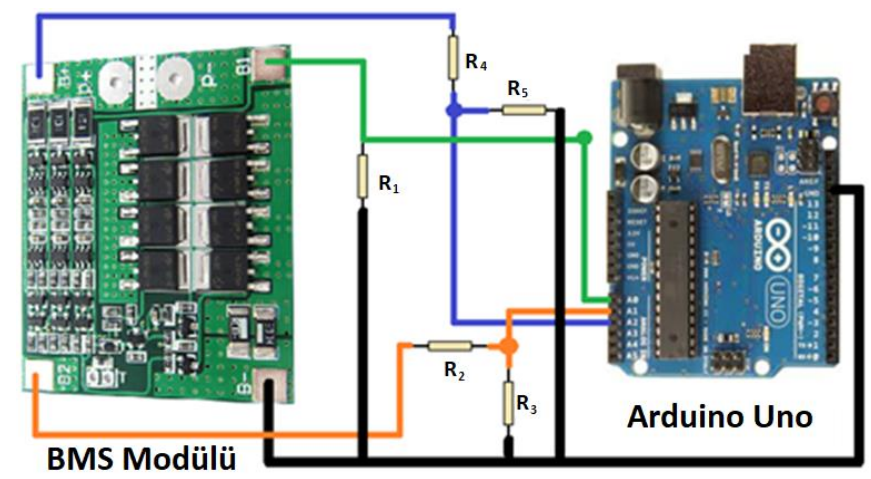

Şekil 4. Şarj Takip Sisteminin Blok Diyagramı

LiPo bataryasının şarj takip sisteminin algoritması Şekil 5'te verilmiştir. Algoritmada ilk olarak sensör kalibrasyonları, seri haberleşme bağlantılarının yapılması gibi kurulumlar yapılmaktadır. Şarj işleminin başlamasının ardından Arduino kartı aracılığıyla seri port üzerinden batarya hücre bilgileri gönderilmektedir. Bilgisayar arayüzü ile seri port üzerinden gönderilen veriler okunmakta ve bu verilere ek olarak anlık tarih ve saat bilgileri eklenmektedir. Elde edilen son kullanıcı verisi ekrana yazdırılarak kullanıcının şarj işlemini takip etmesi sağlanmaktadır. Şarj işlemi bitene kadar bu adımlara devam edilmektedir. Şarj işleminin bitiminde sonra veriler kaydedilerek şarj grafikleri elde edilmektedir.

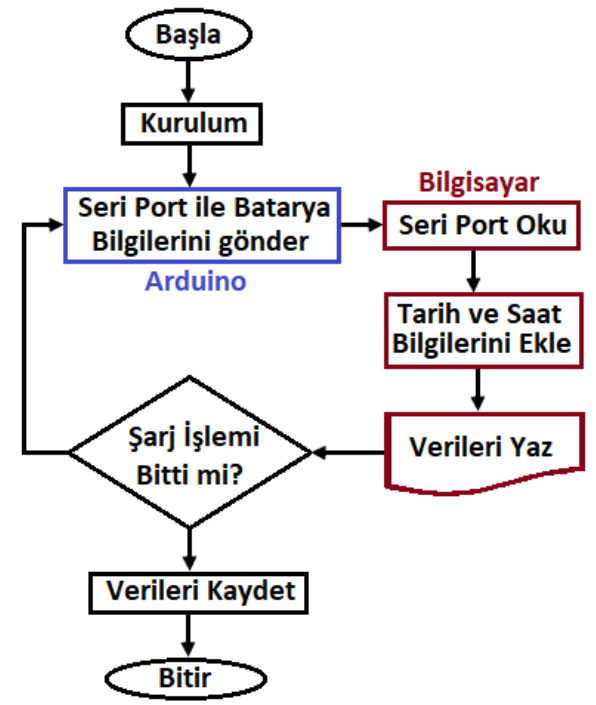

Şekil 5. Şarj Takip Sisteminin Algoritması

\section{UYGULAMA TESTLERI} yapılmıştır.

Çalışma kapsamında dört farklı test işlemi gerçekleştirilmiştir. Test işlemleri aşağıdaki adımları takiben

1. BMS Kartı ile LiPo Bataryasının Şarj Edilmesi

2. BMS Kartı ve Şarj Ped'i ile LiPo Bataryasının Şarj Edilmesi

3. BMS ve Arduino ile LiPo Bataryasının Hücre Bilgilerinin Takip Edilmesi

4. Gerçek Zamanlı Batarya Hücre Bilgilerinin Takip Edilmesi 


\begin{tabular}{|c|c|c|}
\hline & $\begin{array}{l}\text { BŞEÜ Fen Bilimleri Dergisi } \\
8(1), 398-407,2021\end{array}$ & $\begin{array}{r}\text { BSEU Journal of Science } \\
\text { https://doi.org/10.35193/bseufbd.931613 }\end{array}$ \\
\hline & & 2458-7575 (https://dergipark.org.tr/tr/pub/bseufbd) \\
\hline
\end{tabular}

\section{A. BMS Kartı ile LiPo Bataryasının Şarj Edilmesi}

Şekil 6'da BMS şarj kartı ile LiPo bataryaların şarj edilmesine yönelik görsel verilmiştir. Güç kaynağından gelen gerilim değeri ve akım değerleri BMS kartı üzerinden LiPo pili şarj etmek amacıyla kullanılmakta ve balanslı şarj etme işlemi gerçekleştirilmektedir. Ölçümler esnasında LiPo gerilimi "12.28V" olarak görülmektedir. Bu çalışma ile LiPo bataryasının DC gerilim üzerinden şarj edilmesi işlemi gerçekleştirilmiştir. Şarj işlemleri sırasında LiPo bataryasının içerisindeki her hücrenin eşit değerlerde bulunması bataryanın zarar görmemesi için balanslı şarj işlemi yapılmıştır.

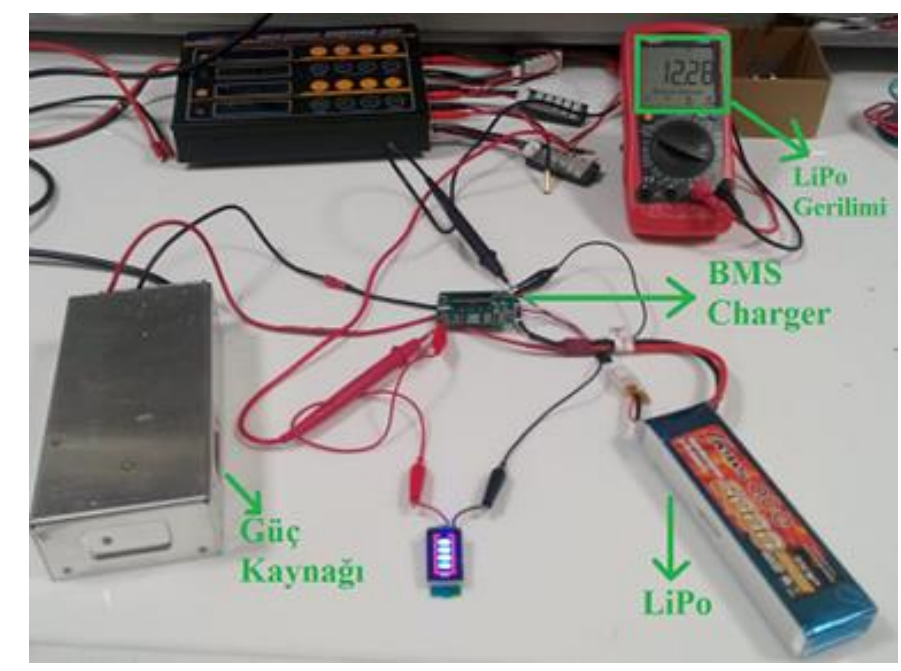

Şekil 6. BMS Kartı ile LiPo Bataryasının Şarj Edilmesi

\section{B. BMS Kartı ve Şarj Pedi ile LiPo Bataryasının Şarj Edilmesi}

Donanımsal olarak şarj ped'i üzerinden LiPo bataryasının şarj edilmesine yönelik görsel Şekil 7'de verilmiştir. DC güç kaynağı ve şarj ped'i arasında kablo bağlantıları yapılarak şarj ped'ine güç verilmiştir. Şarj ped'i üzerindeki "+" ve "-" güç hatları için alüminyum folyolar kullanılmıştır. Konektörlerin bu hatlar ile temas etmesi halinde BMS kartına elektrik aktarımı yapılmaktadır. BMS kartı aracılığıyla LiPo bataryanın balanslı bir şekilde şarj edilmesi sağlanmaktadır. Görseldeki voltmetrede görülen "12.531 V" değeri LiPo bataryanın anlık olarak sahip olduğu voltaj değerini göstermektedir.

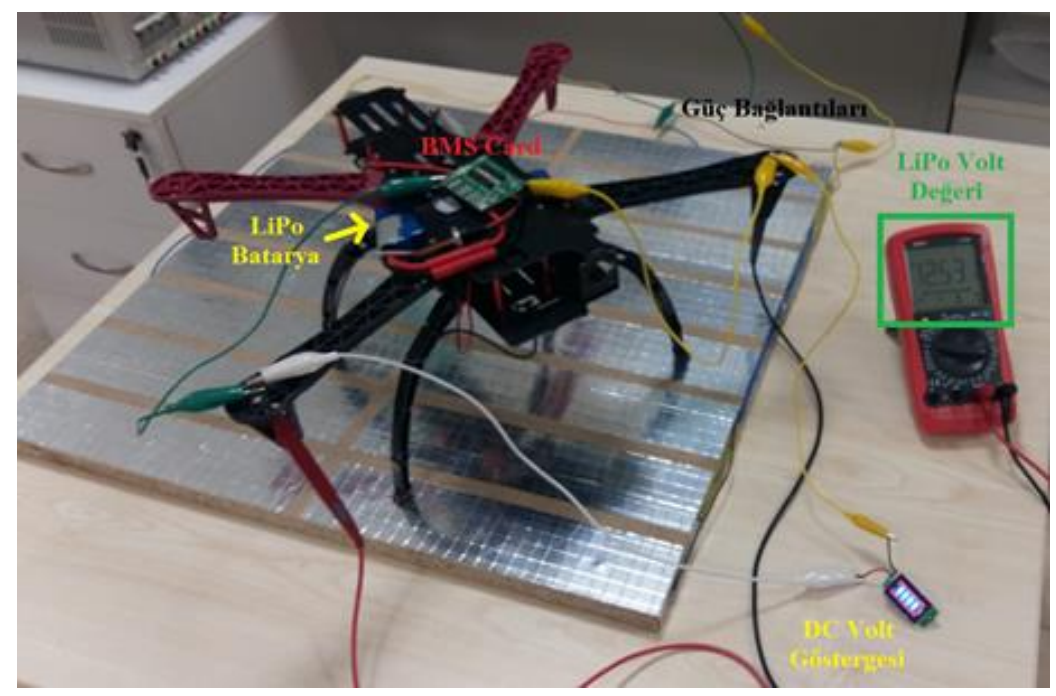

Şekil 7. BMS Kartı ve Şarj Ped’i ile LiPo Bataryasının Şarj Edilmesi 


\begin{tabular}{|c|c|c|}
\hline & $\begin{array}{l}\text { BŞEÜ Fen Bilimleri Dergisi } \\
8(1), 398-407,2021\end{array}$ & $\begin{array}{r}\text { BSEU Journal of Science } \\
\text { https://doi.org/10.35193/bseufbd.931613 }\end{array}$ \\
\hline & & 2458-7575 (https://dergipark.org.tr/tr/pub/bseufbd) \\
\hline
\end{tabular}

\section{BMS ve Arduino ile LiPo Bataryasının Hücre Bilgilerinin Takip Edilmesi}

LiPo batarya hücre voltaj değerlerinin arayüz üzerinden takibine yönelik görsel Şekil 8'de verilmiş̧ir. BMS kartı aracılığıyla Arduino kartına analog gönderilen batarya gerilim değerleri, Arduino içerisinde dijital çevrim işlemlerine tabi tutulmaktadır. Voltaj gerilim değerleri elde edildikten sonra, seri haberleşme birimi aracılığıyla arayüze gönderilmektedir. Arayüzde sırasıyla 1.hücrenin, 2.hücrenin, 3.hücrenin ve toplam gerilim değerleri gösterilmektedir. Anlık takip yapılabilmesi için o anki tarih ve zaman bilgileri de eklenerek veri satırları oluşturulup ekrandaki forma yazdırılmaktadır. Arayüzde, LiPo bataryasının sahip olduğu gerilim miktarı yüzdelik olarak gösterilmektedir. Yüzde hesabı işlemi yapılırken, LiPo bataryasının en verimli çalıştığı alt ve üst seviyeler olan 11.1V ve 12.6V değerleri seçilmiştir. Yüzde hesabı formülü Denklem 2'de verilmiştir.

$\mathrm{LiPo} \%=\left(\left(\mathrm{V}_{\text {LiPo }}-\mathrm{V}_{\text {AltSeviye }}\right) /\left(\mathrm{V}_{\text {UstSeviye }}-\mathrm{V}_{\text {AltSeviye }}\right)\right) * 100$

\begin{tabular}{|c|c|c|c|c|c|c|c|c|}
\hline 2 LIPOB & tarya Şarj Takip U & Imasa & & & & & - & $\square$ \\
\hline \multirow{10}{*}{$\begin{array}{l}\text { Port } \\
\text { Seçimi }\end{array}$} & \multirow{2}{*}{\multicolumn{2}{|c|}{ COM5 }} & \multirow{9}{*}{$\begin{array}{l}14.04 .202115: 05: 01 \\
14.04 .202115: 05: 04 \\
14.04 .202115: 05: 07 \\
14.04 .202115: 05: 10 \\
14.04 .202115: 05: 13 \\
14.04 .202115: 05: 16 \\
14.04 .202115: 05: 19 \\
14.04 .202115: 05: 22 \\
14.04 .202115 .05: 25 \\
14.04 .202115: 05: 28\end{array}$} & \multirow{9}{*}{$\begin{array}{l}3.86 \\
3.86 \\
3.86 \\
3.86 \\
3.86 \\
3.86 \\
3.86 \\
3.86 \\
3.86 \\
3.86\end{array}$} & \multirow{9}{*}{$\begin{array}{l}3.87 \\
3.87 \\
3.87 \\
3.87 \\
3.87 \\
3.87 \\
3.87 \\
3.87 \\
3.87 \\
3.87 \\
\end{array}$} & \multirow{9}{*}{$\begin{array}{l}3.95 \\
3.95 \\
3.95 \\
3.95 \\
3.95 \\
3.95 \\
3.95 \\
3.95 \\
3.95 \\
3.95\end{array}$} & \multirow{9}{*}{$\begin{array}{l}11.68 \\
11.68 \\
11.68 \\
11.68 \\
11.68 \\
11.68 \\
11.68 \\
11.68 \\
11.68 \\
11.68\end{array}$} & \\
\hline & & & & & & & & \\
\hline & Seri llețşimi & Seri lletişimi & & & & & & \\
\hline & Başlat & Durdur & & & & & & \\
\hline & & \multirow{5}{*}{ Çıkıș } & & & & & & \\
\hline & Kayit & & & & & & & \\
\hline & Stirla & & & & & & & \\
\hline & & & & & & & & \\
\hline & & & & & & & & \\
\hline & & & $\begin{array}{c}\text { LiPo Voltaj } \\
\text { Degeri }\end{array}$ & & & & & $\begin{array}{c}\text { Lipo Şarj } \\
\% 41\end{array}$ \\
\hline
\end{tabular}

Şekil 8. Arayüz ile batarya hücrelerinin takibi

Arayüz üzerinden takip işlemi yapılırken kullanılan devre, Şekil 9'da verilmiştir. Şekilde BMS kartı, gerilim bölücü devre, Arduino kartı ve LiPo bataryasının bağlantıları verilmiştir.

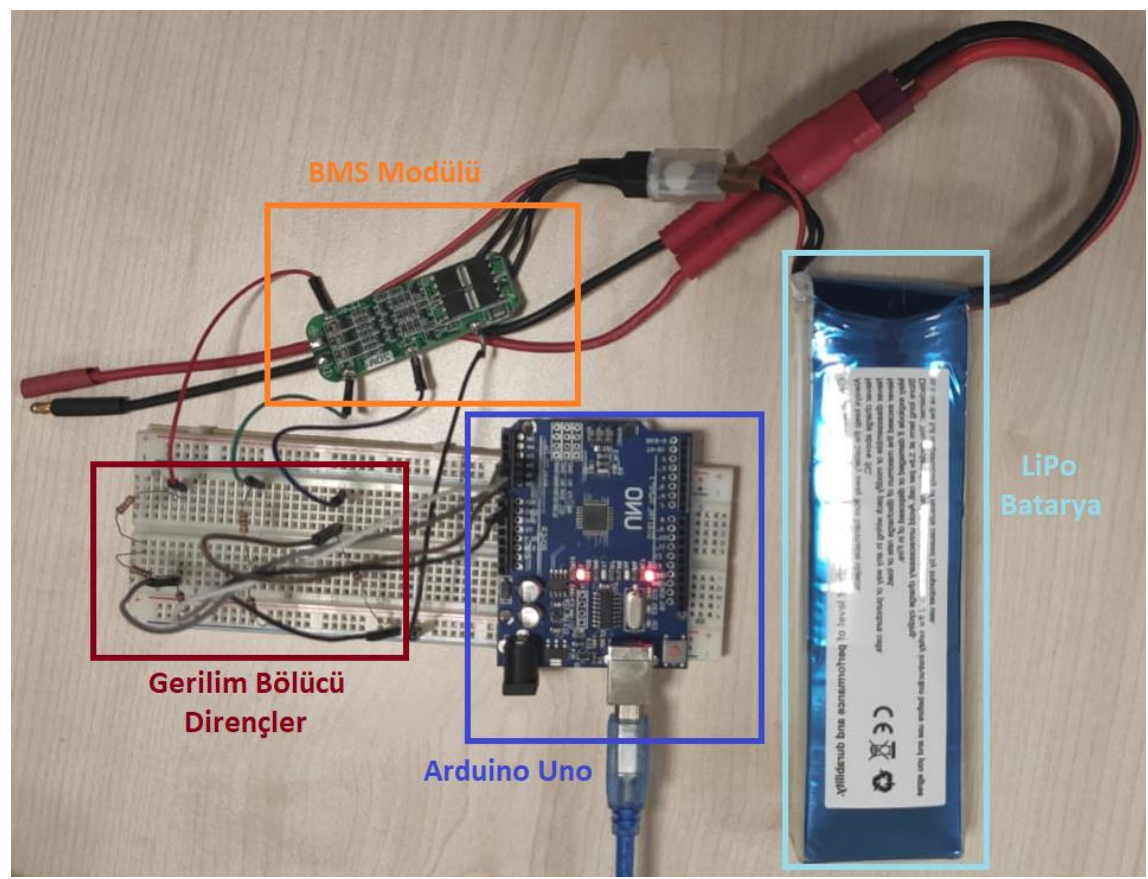

Şekil 9. Şarj takip devresi 


\begin{tabular}{|c|c|c|}
\hline & $\begin{array}{l}\text { BŞEÜ Fen Bilimleri Dergisi } \\
8(1), 398-407,2021\end{array}$ & $\begin{array}{r}\text { BSEU Journal of Science } \\
\text { https://doi.org/10.35193/bseufbd.931613 }\end{array}$ \\
\hline $\begin{array}{l}\text { BiLECIKSEYY EDE } \\
\text { ONIVERSIT }\end{array}$ & & 2458-7575 (https://dergipark.org.tr/tr/pub/bseufbd) \\
\hline
\end{tabular}

\section{Gerçek Zamanlı Batarya Hücre Bilgilerinin Takip Edilmesi}

LiPo batarya gerilim bilgilerinin şarj esnasında takip edilmesi işlemi çalışma kapsamında temel amaç olarak ele alınmıştır. Bu amacı gerçekleştirmeden önce belirli test aşamalarından başarıyla geçilmiş ve uygulamanın son adımında şarj takip sistemi bütünsel olarak ele alınmıştır. Bu adımda şarj ped'i aracılığıyla şarj edilen LiPo bataryasının anlık verileri arayüze gönderilmiş ve şarj işleminin sonucunda alınan veriler üzerinden şarj grafikleri elde edilmiştir. Şekil 10'da şarj işlemine ait görsel verilmiştir. Şarj ped'i üzerindeki İHA'nın bacaklarına bağlanan konektörler üzerinden enerji akışı sağlanmaktadır. Elde edilen enerji BMS kartına bağlı olan bataryayı şarj etmek için kullanılmaktadır. BMS kartı üzerinden yapılan şarj işlemi esnasında paralel olarak hücre bilgileri de Arduino kartına gönderilmektedir.

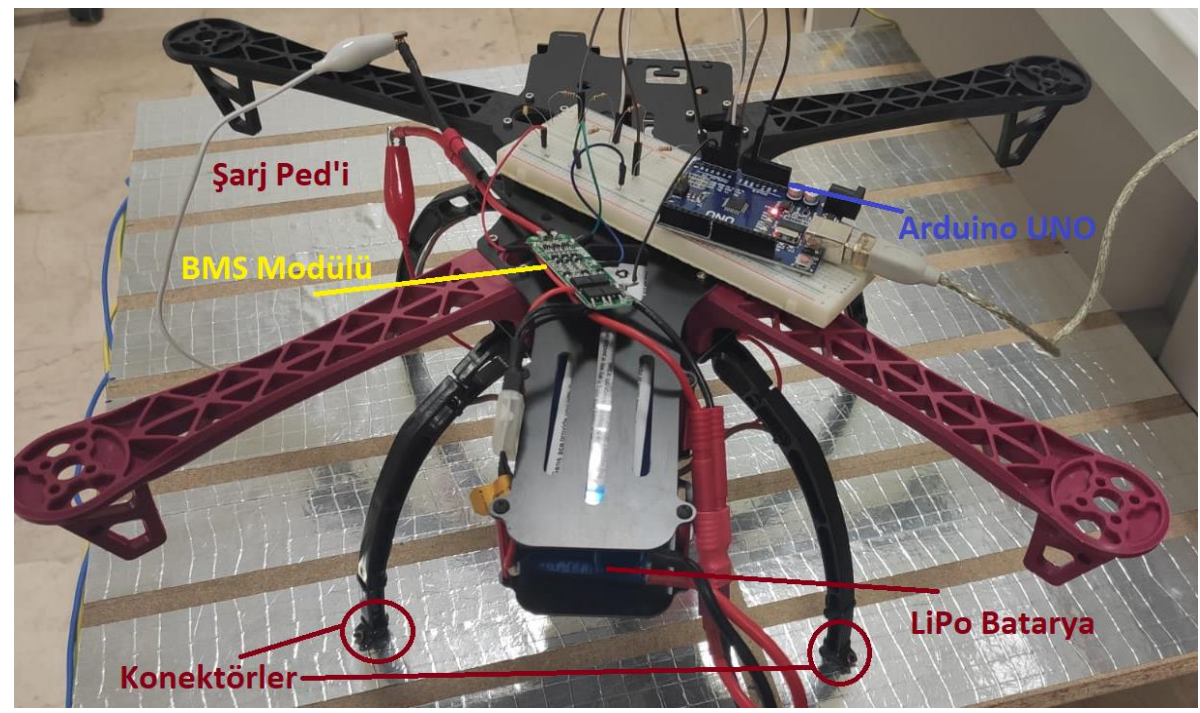

Şekil 10. Batarya şarj ve anlık hücre voltajı takip sistemi

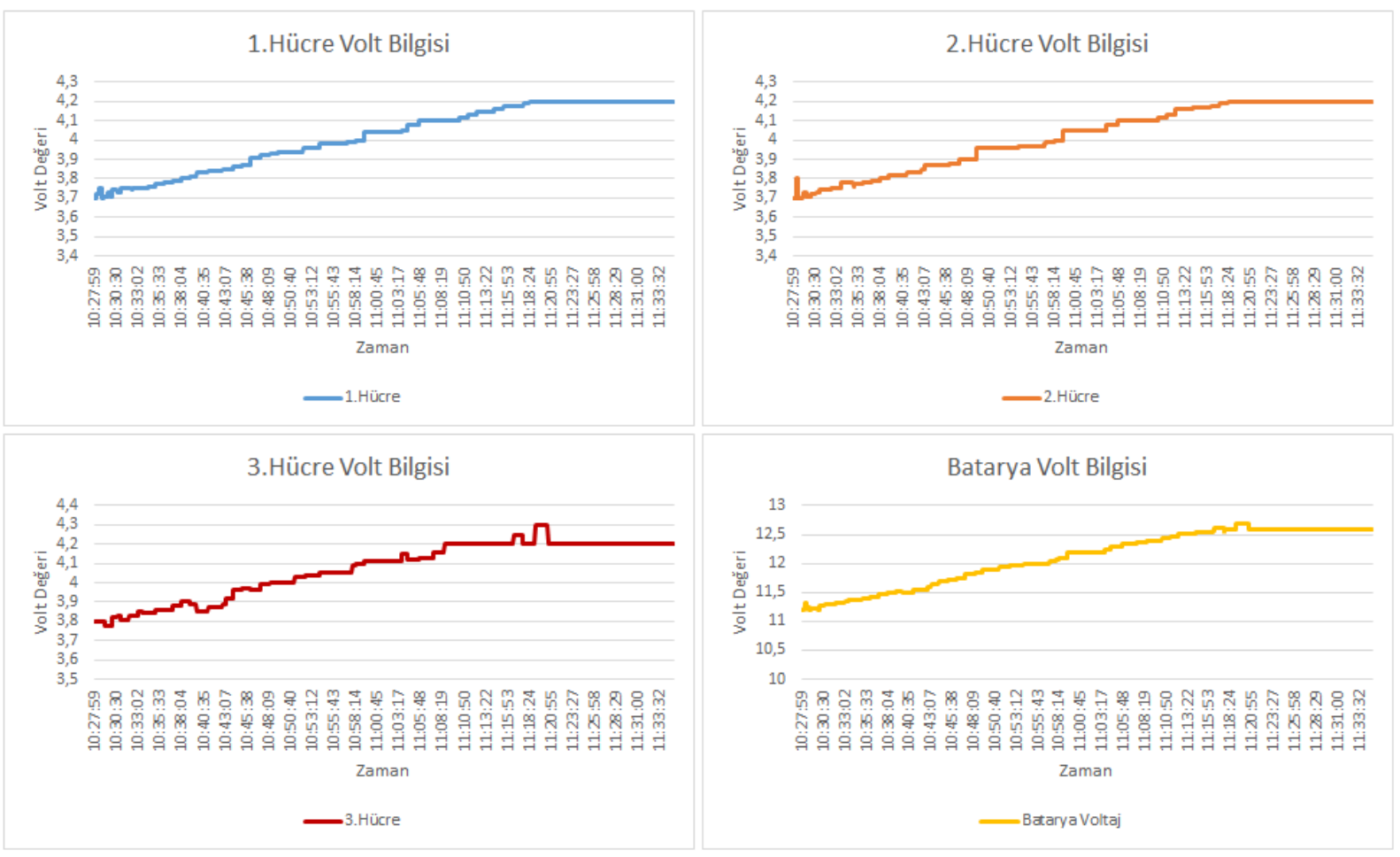

Şekil 11. LiPo Batarya Şarj Grafikleri 
. Şarj işlemlerinde güvenlik amacıyla gerçek donanımlı İHA yerine sadece İHA çerçevesi kullanılmıştır. Şarj işlemi sırasında arayüze gönderilen hücre voltaj değerleri ve toplam batarya voltaj değeri, şarj işleminin bitiminden sonra kaydedilmiştir. Kaydedilen değerler, grafiksel olarak Şekil 11'de verilmiştir. Grafiklerde, LiPo bataryasının hücresel ve toplam voltaj değerleri gösterilmektedir. Yapılan şarj işlemi balanslı olarak gerçekleştirilmiştir ve hücrelerdeki voltaj seviyesindeki artış miktarı eşit seviyeli olarak görülmektedir.

\section{SONUÇ}

LiPo bataryalar yüksek yoğunluklu enerjileri, küçük boyutları, düşük ağırlıkları ve tekrar tekrar şarj edilmeleri sebebiyle elektronik uygulamalarda sıkça kullanılan bataryalardan bir tanesi haline gelmiştir. Hücreli yapıya sahip LiPo bataryaların şarj işlemleri sırasında, yüksek akım çekmesi, yüksek sıcaklık ve basınç, kaçak akım riski, farklı hücre seviyeleri gibi bazı problemler meydana gelebilmektedir. Bu problemler bataryanın yapısının bozulmasına neden olmaktadır. Bu gibi sorunların üstesinden gelmek amacıyla batarya yönetim sistemleri kullanılmaktadır. Batarya yönetim sistemi (BMS) bir veya daha çok hücreden oluşan batarya hücrelerinin şarj ve deşarj işlemleri sırasında bataryaların denetimini ve yönetimini yapan sistemlerdir. Batarya hücrelerinde akım, gerilim, sıcaklık vb. önemli değerlerin ölçümünü yaparak, uygun değerlerin dışına çıkıldığında sisteme müdahale eden yapılardır. BMS'ler, şarj edilebilir bataryaların kontrol ve denetimini yapan elektronik sistemlerdir.

Bu çalışma kapsamında, BMS modülü aracılı̆̆ıyla LiPo bataryasının şarj edilmesi ve şarj esnasında LiPo bataryasının hücrelerindeki voltaj değerlerinin takip edilmesine imkân sağlayan bir şarj sistemi geliştirilmiştir. Şarj işlemi esnasında BMS modülü ile Arduino kart arasında kurulan gerilim bölücü devresiyle batarya hücrelerinin ayrı ayrı voltaj değerleri alınmış ve analog değer olarak Arduino kartına gönderilmiştir. Arduino içerisinde yapılan dönüşüm işlemlerinden sonra elde edilen voltaj değerleri seri haberleşme protokolü ile kullanıcılar için geliştirilen arayüze gönderilmiştir. Arayüz ile şarj işlemi esnasında hücre voltaj bilgileri anlık ve gerçek zamanlı olarak kullanıcılara gösterilmektedir. Gerçek zamanlı takip işlemi ile şarj işleminde meydana gelebilecek problemlere anında müdahale edilip şarj işleminin kesilmesi sağlanabilmektedir.

$\mathrm{Bu}$ işlemlerin bir araya getirilmesi esnasında adım adım test işlemleri gerçekleştirilmiştir. Test işlemlerinde genel olarak, şarj süreçlerinin başarılı bir şekilde yapılması ve veri transferinin sorunsuz bir şekilde gerçekleştirilmesi ele alınmıştır. Test adımları başarılı bir şekilde geçildikten sonra uygulamanın son adımı olan birleştirme işlemine geçilmiştir. Son adımda hem şarj işlemi hem de voltaj değerlerinin takibi işlemi yapılmıştır. İlerleyen çalışmalarda, bataryanın akım ve sıcaklık değerlerinin takibi ve tam donanımlı bir İHA kullanılarak şarj işleminin yapılması planlanmaktadır.

\section{TESSEKKÜR}

Yazarlar, 2017-02.BŞEÜ.03-05 no’lu proje kapsamında, Bilecik Şeyh Edebali Üniversitesi'nin verdiği destek için teşekkür eder.

\section{KAYNAKLAR}

[1] Sierra, G., Orchard, M., Goebelb, K. \& Kulkarnid C. (2019). Battery health management for small-size rotary-wing electric unmanned aerial vehicles: An efficient approach for constrained computing platforms. Reliability Engineering and System Safety, 182, 166-178.

[2] Legowo, A., Sulaeman, E. \& Rosli, D. (2019). Review on System Identification for Quadrotor Unmanned Aerial Vehicle (UAV). Advances in Science and Engineering Technology International Conferences (ASET). Dubai, United Arab Emirates, 8.

[3] Hayat, S., Yanmaz, E. \& Muzaffar, R. (2016). Survey on Unmanned Aerial Vehicle Networks for Civil Applications: A Communications Viewpoint. IEEE Communications Surveys \& Tutorials, 18, 2624-2661.

[4] Bronz, M., Moschetta, J.M., Brisset, P. \& Gorraz, M. (2009). Towards a Long Endurance MAV. International Journal of Micro Air Vehicles, 1, 241-254.

[5] Hassanalian, M. \& Abdelkefi, A. (2017.) Classifications, applications, and design challenges of drones: A review. Progress in Aerospace Sciences, 91, 99-131.

[6] Yang, X., Jiang, H. \& Deng, Z. (2015). Design of a Battery Management System Based on Matrix Switching Network. IEEE International Conference on Information and Automation, Lijiang, China, 141.

[7] Cao, J. \& Emadi, A. (2011). Batteries need electronics. IEEE Industrial Electronics Magazine, 5(1), 7-35.

[8] Gatti, M., Giulietti, F. \& Turci, M. (2015). Maximum endurance for battery-powered rotary-wing aircraft. Aerospace Science and Technology, 45, 174-9. 
[9] Pola, D. A., Navarrete, H. F., Orchard, M. E., Rabie, R. S., Cerda, M. A., Olivares, B. E., Silva, J. F., Espinoza, P. A. \& Perez, A. (2015). Particle-filtering-based discharge time prognosis for lithium-ion batteries with a statistical characterization of use profiles. IEEE Transactions on Reliability, 64(2), 710-20.

[10] Baronti, F., Fantechi, G., Leonardi, E., Roncella R. \& Saletti, R. (2011). Hierarchical platform for monitoring, managing and charge balancing of LiPo batteries. IEEE Vehicle Power and Propulsion Conference, Chicago, IL, USA, 6.

[11] Carkhuff, B. G., Demirev, P. A. \& Srinivasa, R. (2018). Impedance-Based Battery Management System for Safety Monitoring of Lithium-Ion Batteries. IEEE Transactions on Industrial Electronics, 65(8), 6497-6504.

[12] Marhoon, H. M. \& Taha I. A. (2018). Design and Implementation of Intelligent Circuit Breaker for Electrical Current Sensing and Monitoring. International Journal of Core Engineering \& Management, 4(11), 39-49.

[13] Kondaveeti, H. K., Kumaravelu, N. K., Vanambathina, S. D., Mathe, S. E. \& Vappangi, S. (2021). A systematic literature review on prototyping with Arduino: Applications, challenges, advantages, and limitations. Computer Science Review, 40, 100364.

[14] Merev, A. \& Kalenderli, O. (2006). 100 ppm'den Küçük Ölçüm Belirsizliğine Sahip 100 kV Yüksek Doğru Gerilim Bölücüsü. ITÜ Dergisi/D - Mühendislik, 5(3), 39-50. 